\title{
Peningkatan Hasil Belajar IPA Materi Konsep Perubahan Wujud Benda Melalui Metode Eksperimen pada Peserta Didik Kelas V SDN No. 30 INP Kaida
}

\author{
Muh. Ishak Basri ${ }^{*}$, Rahmat Abdul Layn', \\ Rivan$^{1}$, Nurmadina ${ }^{1}$, Sri Sulfa Dewi ${ }^{1}$, Muh. Ahsan ${ }^{1}$ \\ 1. Universitas Terbuka \\ *email: muhishakbasri877@gmail.com
}

\begin{abstract}
Abstrak
Pendidikan merupakan salah satu faktor penting dalam pertumbuhan suatu bangsa. Berdasarkan pemikiran tersebut, maka perlu dilakukan upaya peningkatan kualitas proses belajar mengajar khususnya pada mata pelajaran IPA konsep perubahan wujud benda dengan melaksanakan penelitian tindakan kelas dengan tujuan meningkatkan kualitas pembelajaran peserta didik dalam berbagai aspek khususnya dalam upaya peningkatan hasil belajar peserta didik dengan menggunakan metode eksperimen. Penelitian tindakan kelas ini dilaksanakan dalam dua siklus pembelajaran dengan setiap siklus terdiri dari perencanaan, pelaksanaan, observasi, evaluasi serta refleksi. Waktu penelitian pada bulan April di kelas V SDN No. 30 Inp Kaida Kecamatan Pamboang Kabupaten Majene dengan jumlah peserta didik 15 orang, adapun hasil tes pada siklus I adalah $48,8 \%$ tuntas belajar, dengan persentase nilai tinggi $9,4 \%$ dan nilai sedang $39,4 \%$. Kemudian pada siklus II mengalami peningkatan dari $48,8 \%$ tuntas menjadi $84,5 \%$, nilai tinggi dari $9,4 \%$ menjadi $31 \%$ dan nilai sedang menjadi $45 \%$. Dengan demikian dapat disimpulkan bahwa peserta didik dapat mengalami peningkatan hasil belajar pada siklus II dibanding siklus I setelah menggunakan metode eksperimen.
\end{abstract}

Kata Kunci: Hasil Belajar, Metode Eksperimen, Peningkatan.

\section{PENDAHULUAN}

Belajar dan mengajar merupakan dua konsep yang tidak bisa dipisahkan satu sama lain. Belajar menunjuk pada apa yang harus dilakukan seseorang sebagai subyek yang menerima pelajaran (sasaran didik), sedangkan mengajar menunjuk pada apa yang harus dilakukan oleh guru sebagai pengajar. Belajar adalah kegiatan berproses dan merupakan unsur yang fundamental dalam penyelenggaraan jenis dan jenjang pendidikan artinya keberhasilan pencapaian tujuan pendidikan sangat tergantung pada keberhasilan proses belajar peserta didik di sekolah dan lingkungan sekitar (Jihad, 2012).

Seiring dengan perkembangannya ilmu pengetahuan dan teknologi paradigma pembelajaran di sekolah banyak mengalami perubahan, terutama dalam pelaksanaan proses pembelajaran dari yang bersifat behavioristik menjadi konstruvistik,dari berpusat pada guru (teaching centered) menuju berpusat pada peserta didik (student centered).

Ilmu Pengetahuan Alam disusun dan diperoleh melalui metode ilmiah. Untuk anak SD, metode ilmiah dikembangkan secara bertahap dan berkesinambungan, dengan harapan bahwa 
pada akhirnya akan terbentuk paduan yang lebih utuh sehingga anak SD dapat melakukan penelitian sederhana. Disamping itu, pertahapan perkembangannya disesuaikan dengan tahapan proses penelitian atau eksperimen, yang meliputi : observasi, klasifikasi, interpretasi, prediksi, hipotesis, mengendalikan variabel, merencanakan dan melaksanakan penelitian, inferensi, aplikasi, dan komunikasi. Untuk memahami konsep, peserta didik tidak diberitahu guru, tetapi guru memberi peluang pada peserta didik untuk memperoleh dan menemukan konsep melalui pengalaman peserta didik melalui percobaan dan membuat kesimpulan. Oleh karena itu metode eksperimen salah satu metode yang cocok diterapkan pada mata pelajaran Ilmu Pengetahuan Alam. Dengan metode eksperimen kemampuan intelektual peserta didik dapat dikembangkan oleh guru, peserta didik bisa menghayati bagaimana ilmu diperoleh serta memperoleh daya ingat yang lebih lama retensinya.

Berdasarkan wawancara yang dilakukan oleh peneliti terhadap guru kelas V di SDN No. 30 Inp Kaida Kecamatan Pamboang Kabupaten Majene, pada kenyataannya guru masih menerapkan metode ceramah dalam pembelajaran. Peserta didik hanya sebagai pendengar sehingga kurang melibatkan aktivitas peserta didik secara langsung. Peserta didik hanya dianggap sebagai gelas kosong yang harus diisi penuh tanpa memperhatikan pengetahuan yang dibawa peserta didik. Akan tetapi guru mengaku pernah sesekali menggunakan metode diskusi dalam proses pembelajaran. Mengingat waktu dan target pengajaran materi yang telah ada di sekolah, metode ceramah dianggap sebagai metode paling cepat dalam menyelesaikan materi pengajaran. Metode ceramah yang digunakan oleh guru, pembelajaran guru kurang variatif, serta kurangnya sarana prasarana sebagai media dalam pembelajaran IPA menyebabkan 51,2\% peserta didik memperoleh nilai dibawah KKM. Nilai KKM pada mata pelajaran IPA SDN No. 30 Inp Kaida Kecamatan Pamboang Kabupaten Majene adalah 65.

Berdasarkan informasi dari guru diperoleh bahwa 9 peserta didik dari jumlah seluruh peserta didik 15 memperoleh nilai di bawah KKM, guru harus memahami karasteristik peserta didik dan mencari metode yang seperti apa yang bisa memotivasi peserta didik sehingga peserta didik senang belajar dan terlibat langsung dengan sesuatu yang nyata dalam proses pembelajaran. Peserta didik dapat memperoleh nilai di atas KKM.

Observasi yang dilakukan peneliti pada waktu proses pembelajaran IPA dimana guru menggunakan metode ceramah dalam menyampaikan materi sehingga peserta didik tidak aktif dalam proses pembelajaran. Guru perlu memperhatikan metode yang tepat dalam proses pembelajaran sehingga peserta didik dapat terlibat secara langsung, dan peserta didik bisa mengamati secara langsung sehingga peserta didik dapat memperoleh pengetahuan itu sendiri tanpa diberitahukan oleh guru karena dalam proses pembelajaran guru berperan sebagai pembimbing dan fasilitator untuk peserta didik.

Berdasarkan permasalahan yang telah dituliskan tersebut maka untuk mengatasi rendahnya hasil belajar peserta didik terhadap pelajaran IPA materi konsep perubahan wujud benda di kelas V SDN No. 30 Inp Kaida Kecamatan Pamboang Kabupaten Majene maka peneliti berinisiatif untuk melakukan penelitian dengan menggunakan metode eksperimen terhadap perubahan wujud benda. Dengan melakukan metode eksperimen diharapkan peserta didik aktif dan termotivasi untuk belajar mata pelajaran IPA sehingga akan meningkatkan hasil belajar peserta didik terhadap pelajaran IPA. 
Adapun tujuan penelitian adalah untuk meningkatkan hasil belajar IPA materi konsep perubahan wujud benda melalui metode eksperimen pada peserta didik di Kelas V SDN No. 30 Inp Kaida Kecamatan Pamboang Kabupaten Majene sehingga peserta didik semakin aktif dan semakin bersemangat dalam mempelajari pelajaran IPA.

\section{Metode}

Metode yang dilakukan dalam penelitian ini adalah metode eksperimen, cara penyajian bahan pelajaran dimana peserta didik melakukan percobaan dengan mengalami untuk membuktikan sendiri sesuatu pertanyaan atau hipotesis yang dipelajari. Metode eksperimen adalah suatu cara mengajar, dimana peserta didik melakukan suatu percobaan tentang sesuatu hal, mengamati prosesnya serta menuliskan hasil percobaannya, kemudian hasil pengamatan itu disampaikan ke kelas dan dievaluasi oleh guru.

Prosedur penelitian yang dilakukan pada penelitian ini menggunakan metode Penelitian langsung. Pelaksanaan penelitian langsung yaitu pada bulan April 2019. Kegiatan meliputi perencanaan, pelaksanaan, perbaikan, monitoring dan refleksi. Penelitian dilaksanakan dalam 2 siklus. Yang dilakukan untuk setiap siklus pembelajaran dalam prosedur penelitian ini adalah sebagai berikut:

a. Tahap Perencanaan

Pada tahapan ini guru melakukan perencanaan perbaikan dengan langkah-langkah berikut:

1) Guru merencanakan perbaikan berdasarkan hasil refleksi pra perbaikan yaitu menyusun langkah-langkah mengatasi masalah rendahnya hasil belajar peserta didik mata pelajaran IPA.

2) Menyusun Rencana Pelaksanaan Pembelajaran (RPP) sebagai acuan pelaksanaan proses pembelajaran dengan berdasarkan kurikulum yang berlaku. Penyusunan RPP ini juga disesuaikan dengan langkah-langkah pada metode pembelajaran yang diterapkan, dalam hal ini metode Eksperimen.

3) Menyusun lembar observasi aktivitas peserta didik

4) Menyusun tes akhir setiap siklus

b. Tahap Pelaksanaan

Pada tahapan ini pelaksanaannya didasarkan rencana pembelajaran yang disusun sebelumnya dengan kegiatan sebagai berikut:

1) Kegiatan awal

a) Guru membuka pelajaran dengan salam

b) Melakukan doa bersama mengawali pembelajaran

c) Guru mengabsen kehadiran peserta didik

d) Apersepsi

2) Kegiatan Inti

a) Guru menjelaskan pengertian wujud zat

b) Guru menjelaskan macam-macam dan sifatnya benda padat cair dan gas

c) Guru membagi peserta didik dalam kelompok dan memberi tugas masing-masing kelompok

d) Guru mengajak peserta didik untuk berdiskusi dan menemukan jawaban yang paling tepat dan memastikan semua kelompok 
e) Guru meminta peserta didik untuk mengerjakan latihan soal yang sudah di sediakan oleh guru.

f) Guru memberikan apresiasi setiap hasil kerja peserta didik. Dan menanyakan kepada peserta didik tentang materi yang belum dipahami.

3. Kegiatan Akhir

a) secara individu peserta didik mengerjakan tes formatif

b) guru melakukan penilaian

c. Tahap Pengamatan dan Pengumpulan Data

Tahap pengumpulan data dilakukan untuk mendapatkan data tentang pelaksanaan perbaikan yaitu:

1) Pengamatan dan pencatatan data tentang pelaksanaan rencana perbaikan pembelajaran dengan menggunakan lembar observasi guru.

2) Pengamatan terhadap partisipasi peserta didik dalam mengikuti proses pembelajaran dengan menggunakan lembar pengamatan peserta didik.

3) Data hasil belajar peserta didik dengan melakukan analisa terhadap hasil tes akhir pelajaran.

Pada tahap ini, selain pengerjaan lembar observasi untuk membuktikan pengamatan yang dilaksanakan, perlu bukti dokumentasi berupa pengambilan gambar jika diperlukan agar dalam penginterpretasian data dapat lebih jelas dan cermat.

d. Tahap refleksi

Pada tahap ini data-data yang diperoleh dari tiap siklus dikumpulkan untuk dianalisis selanjutnya diadakan refleksi terhadap hasil analisis sehingga dapat diketahui ada tidaknya peningkatan hasil belajar sebelum tindakan dan sesudah tindakan. Hasil belajar inilah yang nantinya digunakan sebagai bahan pertimbangan pelaksanaan siklus berikutnya.

Dalam penelitian ini ada dua jenis data yaitu data yang berbentuk kuantitatif dan data yang berbentuk kualitatif.

1. Data Kualitatif

Data kualitatif diantaranya adalah deskripsi data yang menggambarkan hasil pengamatan observer terhadap aktivitas peserta didik selama berlangsungnya pembelajaran.

2. Data kuantitatif

Data-data kuantitatif di antaranya adalah hasil tes individu IPA dan angka persentase keaktifan peserta didik yang diketahui melalui penilaian lembar observasi peserta didik. Data kuantitatif berupa nilai hasil belajar peserta didik tersebut dapat dianalisis dengan cara mencari nilai rata-rata atau persentase keberhasilan belajar dan lain-lain.

Dalam menganalisis tingkat keberhasilan peserta didik setelah kegiatan belajar mengajar pada setiap siklusnya dilakukan dengan cara memberikan evaluasi atau penilaian berupa tes tertulis pada setiap akhir siklus. Untuk teknik penguasaan peserta didik terhadap materi belajar digunakan kategori tingkat penguasaan sumber kemendikbud : 


\section{Tabel 1. Rentang Nilai Peserta Didik}

\begin{tabular}{cc}
\hline Kategori & Rentang Nilai \% \\
\hline Kurang & $0 \%-64 \%$ \\
Sedang & $65 \%-75 \%$ \\
Tinggi & $76 \%-87 \%$ \\
Sangat Tinggi & $88 \%-100 \%$ \\
\hline
\end{tabular}

Untuk mengetahui peningkatan hasil belajar peserta didik. Rumus yang digunakan untuk menghitung persentase nilai adalah:

$$
\text { Nilai rata-rata: }(\mathrm{X})=\frac{\text { Jumla seluruh nilai peserta didik }}{\text { JumlahsemuaPesertadidik }(\mathrm{X})}
$$

Rumus tersebut tersebut digunakan untuk memperoleh nilai rata-rata kelas hasil tes formatif. Sedangkan untuk menghitung persentase ketuntasan belajar digunakan rumus yaitu:

$$
\mathrm{P}(\text { Persentase })=\frac{\text { peserta didik tuntas belajar }}{\text { Jumlah seluruh peserta didik }} \times 100 \%
$$

\section{Hasil}

Setelah pelaksanaan penelitian perbaikan pembelajaran pada mata pelajaran IPA, konsep perubahan wujud benda dengan menggunakan metode eksperimen pada peserta didik kelas $\mathrm{V}$ SDN No. 30 Inp Kaida Kecamatan Pamboang Kabupaten Majene yang dilaksanakan pada bulan April dengan 2 (dua) siklus perbaikan.

Data jumlah peserta didk dalam sebuah pembelajaran IPA baik sebelum perbaikan dan setelah perbaikan diketahui melalui pengamatan observasi dan pemberian tes tertulis pada setiap akhir siklus.

1. Hasil Tes Formatif Siklus I dalam Pembelajaran IPA

Adapun skor perolehan hasil ulangan harian tes tertulis pembelajaran IPA siklus I disajikan dalam tabel 2.

Tabel 2. Hasil Belajar dalam Pembelajaran IPA Siklus I

\begin{tabular}{llccc}
\hline No & Nama Peserta Didik & KKM & Nilai & Tuntas/Tidak Tuntas \\
\hline 1 & MZP & 65 & 70 & Tuntas \\
2 & SSK & 65 & 50 & Tidak Tuntas \\
3 & NRM & 65 & 55 & Tidak Tuntas \\
4 & RTN & 65 & 80 & Tuntas \\
5 & WLD & 65 & 45 & Tidak Tuntas \\
6 & SDM & 65 & 40 & Tidak Tuntas \\
7 & APS & 65 & 70 & Tuntas \\
8 & MIH & 65 & 65 & Tuntas \\
9 & SRS & 65 & 45 & Tidak Tuntas \\
10 & HLD & 65 & 55 & Tidak Tuntas \\
11 & NAH & 65 & 45 & Tidak Tuntas
\end{tabular}




\begin{tabular}{|c|c|c|c|}
\hline AND & 65 & 65 & Tuntas \\
\hline MST & 65 & 45 & Tidak Tuntas \\
\hline MFD & 65 & 65 & Tuntas \\
\hline $15 \quad$ JND & 65 & 55 & Tidak Tuntas \\
\hline Jumlah & & 850 & \\
\hline Rata-Rata Kelas & & 57 & \\
\hline Persentase & & & $\begin{array}{c}\text { Tuntas }=48,8 \% \\
\text { Tidak Tuntas }=51,2 \%\end{array}$ \\
\hline
\end{tabular}

Tabel 3. Interval Nilai Frekuensi Pelajaran IPA Kelas V Siklus I

\begin{tabular}{lllcc}
\hline No & Interval nilai & Kategori & Frekuensi & Persentase \\
\hline 1 & $0-64$ & Kurang & 9 & 51,2 \\
2 & $65-75$ & Sedang & 5 & 39,4 \\
3 & $76-87$ & Tinggi & 1 & 9,4 \\
4 & $88-100$ & Sangat Tinggi & - & 0 \\
\hline Jumlah & & 15 & 100 \\
\hline
\end{tabular}

Dengan memperlihatkan tabel 2 terlihat nilai rata-rata kelas hasil belajar peserta didik mata pelajaran IPA konsep perubahan wujud benda adalah 57 dan nilai terendah adalah 40 dan nilai tertinggi 80 dengan jumlah persentase peserta didik yang tuntas adalah $48,8 \%$ dan tidak tuntas adalah 51,2\%, sedangkan pada tabel 3 menunjukkan jumlah peserta didik yang mendapat nilai kurang adalah $51,2 \%$ dengan jumlah peserta didik adalah 9 orang sedangkan pada nilai sedang sejumlah 5 orang $(39.4 \%)$, nilai tinggi 1 orang $(9,4 \%)$, nilai sangat tinggi $(0 \%)$.

Berdasarkan data observasi penilaian kedua tabel tersebut maka dapat dikemukakan bahwa pemahaman peserta didik terhadap mata pelajaran IPA Konsep perubahan wujud benda pada peserta didik di kelas V SDN No. 30 Inp Kaida masih sangat rendah dan belum mencapai target yang diinginkan sebagaimana yang tertulis dalam tujuan pembelajaran. Oleh karena itu, perbaikan perlu dilanjutkan pada siklus berikutnya yaitu siklus II.

2. Hasil Tes Formatif Siklus II Pembelajaran IPA

Setelah menganalisis hasil tes formatif pada pembelajaran Ilmu Pengetahuan Alam (IPA) pada konsep perubahan wujud benda siklus I peneliti menilai bahwa siklus I masih mempunyai kekurangan sehingga mengakibatkan banyak peserta didik yang tidak mencapai nilai tuntas dan hanya sedikit yang mendapatkan nilai tuntas sehingga target hasil tes formatif peserta didik pada siklus I belum tercapai. Peneliti akhirnya melakukan penelitian lanjutan di siklus II dan peneliti kembali memberikan tes formatif disiklus II. Pada hasil tes formatif peserta didik siklus II peneliti melihat target hasil peserta didik yang diinginkan telah tercapai, pada hasil tes formatif siklus II menunjukkan peningkatan terhadap hasil tes nilai yang telah diberikan oleh guru, terlihat pada tabel 4 bahwa jumlah nilai peserta didik yang tuntas mengalami peningkatan serta jumlah nilai peserta didik yang tidak tuntas. Adapun hasil tes formatif yang telah dihasilkan dalam pembelajaran IPA pada materi konsep perubahan wujud benda pada siklus II dapat disajikan pada tabel 4. 
Tabel 4. Hasil Belajar dalam Pembelajaran IPA Siklus II

\begin{tabular}{llccc}
\hline No & Nama Peserta Didik & KKM & Nilai & Tuntas/Tidak Tuntas \\
\hline 1 & MZP & 65 & 85 & Tuntas \\
2 & SSK & 65 & 70 & Tuntas \\
3 & NRM & 65 & 75 & Tuntas \\
4 & RTN & 65 & 90 & Tuntas \\
5 & WLD & 65 & 55 & Tidak Tuntas \\
6 & SDM & 65 & 50 & Tidak Tuntas \\
7 & APS & 65 & 80 & Tuntas \\
8 & MIH & 65 & 80 & Tuntas \\
9 & SRS & 65 & 65 & Tuntas \\
10 & HLD & 65 & 60 & Tidak Tuntas \\
11 & NAH & 65 & 70 & Tuntas \\
12 & AND & 65 & 85 & Tuntas \\
13 & MST & 65 & 65 & Tuntas \\
14 & MFD & 65 & 70 & Tuntas \\
15 & JND & 65 & 65 & Tuntas \\
\hline Jumlah & & 1065 & \\
\hline Rata-Rata Kelas & & 71 & Tuntas $=84,5 \%$ \\
\hline \multicolumn{2}{l}{ Persentase } & & & Tidak Tuntas $=15,5 \%$ \\
\hline
\end{tabular}

Tabel 5. Interval Nilai Frekuensi Pelajaran IPA kelas V Siklus II

\begin{tabular}{lllcc}
\hline No & Interval nilai & Kategori & Frekuensi & Persentase \\
\hline 1 & $0-64$ & Kurang & 3 & 15,5 \\
2 & $65-75$ & Sedang & 7 & 45 \\
3 & $76-87$ & Tinggi & 4 & 31 \\
4 & $88-100$ & Sangat Tinggi & 1 & 8.5 \\
\hline Jumlah & & 15 & 100 \\
\hline
\end{tabular}

Dari data tabel 4 dapat diketahui bahwa setelah meggunakan metode eksperimen, ternyata hasil belajar peserta didik mengalami peningkatan. Pada siklus I terlihat nilai rata-rata kelas hasil belajar peserta didik mata pelajaran IPA konsep perubahan wujud benda adalah 57 dan pada siklus II mengalami peningkatan sebesar 71 dengan nilai tertinggi siklus II adalah 90 dan nilai terendah adalah 50 dengan jumlah persentase peserta didik yang tuntas belajar adalah $84,5 \%$ dan jumlah persentase peserta didik yang tidak tuntas belajar adalah $15,5 \%$. Pada tabel 5 frekuensi peserta didik yang mendapatkan nilai kurang berkurang menjadi 3 orang $(15,5 \%)$ sedangkan nilai sedang mengalami kenaikan menjadi 7 orang dengan persentase sebesar $45 \%$ dan nilai tinggi juga mengalami peningkatan menjadi 4 orang dengan persentase menjadi $31 \%$ dan 1 orang yang mencapai nilai sangat tinggi $(8,5 \%)$.

Dengan demikian berdasarkan hasil observasi, maka peneliti mengemukakan pembelajaran tidak perlu dilanjutkan ke siklus berikutnya, karena hasil belajar yang diinginkan telah mencapai target pencapaian tujuan pembelajaran serta ketuntasan belajar di kelas. 


\section{Pembahasan}

Salah satu faktor yang diperlukan untuk memajukan pembelajaran dalam usaha peningkatan mutu pendidikan di Indonesia adalah faktor peserta didik, oleh sebab itu dalam keseluruhan proses pendidikan di sekolah salah satunya dapat dilihat dari hasil belajar (Dimyati dan Mudjiono, 2009). Pelaksanaan siklus I mata pelajaran IPA konsep perubahan wujud benda pada peserta didik di kelas V SDN No.30 Inp Kaida, siklus I diawali dengan guru melakukan apersepsi yaitu dengan melakukan tes awal berupa pertanyaan lisan yang bertujuan untuk mengetahui kemampuan peserta didik mengenai materi yang akan dibahas yaitu konsep perubahan wujud benda, contoh-contoh perubahan wujud benda yang ada di lingkungan sekitar. Setelah itu guru menyampaikan materi pelajaran yang berhubungan dengan konsep perubahan wujud benda.

Pada kegiatan akhir pembelajaran guru memberikan tes tertulis yang dikerjakan secara mandiri oleh setiap peserta didik. Setelah itu guru memberikan kesimpulan akhir dan penguatan tentang materi pembelajaran yang telah disajikan dan sekaligus pembelajaran di rumah (PR) sebagai tindak lanjut siklus I. Suatu proses pembelajaran pada akhirnya akan menghasilkan kemampuan manusia berupa pengetahuan, sikap, dan keterampilan. Perubahan kemampuan merupakan indikator untuk menunjukan hasil belajar peserta didik. Perubahan perilaku yang harus dicapai tertuang dalam tujuan pembelajaran dan dapat diukur dengan menggunakan tes dan non tes (Warsita, 2008).

Dalam siklus I saat guru menjelaskan materi konsep perubahan wujud benda terdapat beberapa masalah sehingga peserta didik tidak memahami maksud dan tujuan pembelajaran.

1. Pada saat menjelaskan pelajaran, guru kurang teliti memperhatikan keseriusan peserta didik.

2. Hakikat pembelajaran yang disampaikan oleh guru belum terlalu dipahami peserta didik, karena pada saat proses pembelajaran banyak peserta didik kurang perhatian, bercerita atau ribut dan tidak mendengarkan apa saja yang di bahas oleh guru

3. Dalam diskusi kelompok banyak peserta didik yang kurang aktif bekerja sama. Tanya jawab dengan teman kelompok.

Oleh karena itu, berdasarkan hal-hal yang menjadi penyebab hasil belajar kurang maksimal sebagaimana yang telah diuraikan tersebut, maka guru sebagai peneliti harus melakukan perbaikan-perbaikan agar dapat meningkatkan hasil belajar peserta didik pada siklus berikutnya yaitu siklus II.

Pada siklus II pelaksanaan tindakan pembelajaran mata pelajaran IPA konsep perubahan wujud benda, guru mengawali pertemuan dengan melakukan apersepsi yaitu mengajukan pertanyaan tentang contoh-contoh perubahan wujud benda yang terdapat di lingkungan sekitar. Misalnya perubahan benda padat menjadi cair, perubahan terjadinya peristiwa membeku dan menguap. Setelah itu barulah guru menyampaikan materi pembelajaran dengan menggunakan metode eksperimen, sambil menjelaskan guru memberikan contoh nyata sebuah eksperimen proses terjadinya peristiwa membeku, mencair dan menguap. Peserta didik terlihat antusias dengan mengamati setiap kejadian proses terjadinya perubahan wujud benda. Setelah itu guru membagi peserta didik dalam beberapa kelompok kecil, dimana setiap kelompok ada keseimbangan antara peserta didik yang pintar dan tidak. Setiap kelompok kecil terdiri 4-5 orang. Sebelum kelompok melakukan eksperimen sendiri terlebih dahulu guru menjelaskan 
pentingnya kerja sama dalam sebuah kelompok untuk memecahkan masalah atau soal-soal latihan secara bersama-sama sehingga hasil belajar yang ingin dicapai dapat meningkat.

Selanjutnya guru mengajukan pertanyaan lisan tentang hal-hal yang belum jelas termasuk perubahan-perubahan yang terjadi pada wujud benda. Kemudian guru membagikan lembar kerja peserta didik kepada setiap kelompok kecil untuk menyelesaikan soal-soal yang ada dalam lembar kerja peserta didik dalam rentang waktu yang telah ditentukan. Setelah selesai setiap kelompok menyajikan hasil eksperimennya serta memberikan sebuah tanggapan sehingga kelompok lain bisa menanggapi.

Pada kegiatan akhir pembelajaran guru memberikan tes tertulis yang dikerjakan secara mandiri oleh setiap peserta didik. Setelah itu guru memberikan kesimpulan akhir dan penguatan tentang materi pembelajaran yang telah disajikan dan sekaligus pembelajaran di rumah (PR) sebagai tindak lanjut siklus II.

Berdasarkan hasil pengamatan observasi dan hasil belajar yang diperoleh pada siklus II, maka berarti semua kekurangan dan kelemahan yang ditemukan sebagai sumber masalah ketidakberhasilan peserta didik maupun guru dalam proses pembelajaran sudah dilakukan perbaikan-perbaikan secara menyeluruh. Sebagaimana dengan siklus I, setelah semua data observasi hasil belajar dikumpulkan dan dianalisis, berdasarkan hasil pengamatan guru dan teman sejawat terjadi peningkatan hasil belajar peserta didik terbukti dari hasil ulangan harian yang diberikan pada akhir siklus II nilai rata-rata kelas yaitu 71, ketuntasan belajar dari 48,8 ke $84,5 \%$ sehingga demikian target pencapaian yang diharapkan telah memeneuhi persyaratan ketuntasan belajar di kelas.

Dari uraian pembahasan siklus I dan siklus II tersebut, menggambarkan bahwa guru mempunyai peranan penting terhadap keberhasilan peserta didik dalam kegiatan belajar mengajar. Guru bukan hanya berperan sebagai pengajar tetapi juga sebagai fasilitator untuk peserta didik. Pembelajaran adalah proses interaksi peserta didik dengan pendidik dan sumber belajar. Pada suatu lingkungan belajar yang meliputi guru dan peserta didik yang saling bertukar informasi, Agar dapat terjadi proses perolehan ilmu dan pengetahuan, penguaasan, serta pembentukan sikap dan kepercayaan pada peserta didik (Ngalim, 1997).

Setiap individu belajar menginginkan hasil yang sebaik mungkin. Oleh karena itu, setiap individu harus belajar dengan sebaik-baiknya supaya prestasinya berhasil dengan baik. Hasil belajar peserta didik dapat memiliki pengetahuan, pemahaman, dapat menerapkan, melakukan analisis, sintesis, dan mengevaluasi. Selain itu peserta didik dapat melakukan penerimaan, partisipasi, menentukan sikap, dan mengevaluasi. Selain itu peserta didik dapat melakukan penerimaan, partisipasi, menentukan sikap, mengorganisasikan dan membentuk pola hidup. Selanjutnya peserta didik dapat mempersepsi, bersiap diri, membuat gerakan-gerakan sederhana dan komplek, membuat penyesuaian pola gerak dan menciptakan gerakan baru (Dimyati dan Mudjiyono, 2009).

\section{Kesimpulan}

Setelah pelaksanaan penelitian yang dilakukan oleh peneliti pada peserta didik kelas V SDN No. 30 Inp Kaida Kecamatan Pamboang Kabupaten Majene dengan menggunakan metode eksperimen pada mata pelajaran IPA konsep perubahan wujud benda maka dapat disimpulkan 
bahwa terjadi peningkatan yang cukup signifikan hasil belajar peserta didik pada materi konsep perubahan wujud benda. Peningkatan hasil belajar pada siklus I dengan nilai rata-rata kelas adalah 57 menjadi 71 pada siklus II, persentase ketuntasan belajar pada siklus I dari 48,8\% menjadi $84,5 \%$. Pada siklus I terdapat 6 orang yang tuntas belajar dan 9 orang yang tidak tuntas. Sementara pada siklus II 12 orang yang tuntas belajar dan 3 orang yang tidak tuntas belajar. Untuk nilai pada siklus I 1 orang yang mendapat nilai tinggi dan 5 orang yang mendapat nilai sedang dan pada siklus II 4 orang mendapat nilai tinggi dan tidak ada peserta didik mendapat nilai rendah. Hal ini menunjukkan bahwa terjadi peningkatan hasil belajar peserta didik setelah menggunakan metode eksperimen.

\section{Referensi}

Dimyati dan Mudjiono. 2009. Belajar dan Pembelajaran. Jakarta: PT Rineka Cipta.

Jihad. 2012. Evaluasi Pembelajaran. Yogyakarta: Multi Pressindo.

Ngalim MP. 1997. Psikologi Pendidikan, Bandung: Remaja Rosdakarya.

Warsita, B. 2008. Teknologi Pembelajaran; Landasan dan Aplikasinya. Jakarta: Rineka Cipta. 